\title{
Fungsionalisasi dan Implikasi Asas Kepentingan Terbaik bagi Anak yang Berkonflik dengan Hukum: Studi Putusan Pengadilan Tinggi Tanjung Karang
}

\author{
Mashuril Anwar ${ }^{\star}$ M. Ridho Wijaya ${ }^{\star \star}$ \\ * Program Magister Ilmu Hukum Universitas Lampung \\ mashurilanwar97@gmail.com

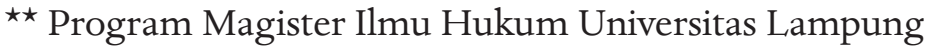 \\ ridhowijayaa@gmail.com
}

\section{Abstract}

The principle of best interest for children requires sanctions of deprivation of liberty as a last resort. Therefore, the principle of the best interests of children must be considered in the resolution of cases of children in conflict with the law. This article, which focuses on the decision of the Tanjung Karang High Court, discusses the functionalization of the best interests principle for children in conflict with the law and the implications of their application. This article concludes, judges in deciding cases of children in conflict with the law in general have not considered the principle of the best interests of the child. Of the 22 cases of children in conflict with the law at the Tanjung Karang High Court in 2011-2016, only three decisions that can be categorized have considered the principle of the best interests of the child. Of the three decisions, two were sentenced not prison and one sentenced to prison. The application of the best interest principle for children in conflict with the law can have both positive and negative implications. It has positive implications, especially for offenders, because it protects children's rights and reduces the burden of court cases and correctional institutions. But it can also have negative implications, because it is feared not to provide a deterrent effect and invite negative public perceptions of the judiciary.

Keywords: child protection; children in conflict with the law; the principle of best interest. 


\section{Abstrak}

Asas kepentingan terbaik bagi anak menghendaki sanksi perampasan kemerdekaan sebagai upaya terakhir. Oleh karenanya, asas kepentingan terbaik bagi anak harus menjadi pertimbangan dalam penyelesaian perkara anak yang berkonflik dengan hukum. Artikel ini, yang berfokus pada putusan Pengadilan Tinggi Tanjung Karang, membahas fungsionalisasi asas kepentingan terbaik bagi anak yang berkonflik dengan hukum dan implikasi penerapannya. Artikel ini menyimpulkan, hakim dalam memutus perkara anak yang berkonflik dengan hukum pada umumnya belum mempertimbangkan asas kepentingan terbaik bagi anak. Dari 22 perkara anak yang berkonflik dengan hukum pada Pengadilan Tinggi Tanjung Karang pada 2011-2016, hanya tiga putusan yang dapat dikategorikan telah mempertimbangkan asas kepentingan terbaik bagi anak. Dari tiga putusan tersebut, dua divonis bukan penjara dan satu divonis penjara. Penerapan asas kepentingan terbaik bagi anak yang berkonflik dengan hukum bisa berimplikasi positif sekaligus negatif. Ia berimplikasi positif terutama bagi pembuat delik, karena melindungi hak-hak anak dan mengurangi beban perkara pengadilan dan lembaga pemasyarakatan. Namun ia juga bisa berimplikasi negatif, karena dikhawatirkan tidak memberikan efek jera dan mengundang persepsi negatif masyarakat terhadap lembaga peradilan.

Kata kunci: perlindungan anak; anak berkonflik dengan hukum; asas kepentingan terbaik.

\section{A. Pendahuluan}

Artikel ini membahas fungsionalisasi asas kepentingan terbaik bagi anak yang berkonflik dengan hukum. Pembahasan ini didasarkan pada pertimbangan bahwa asas kepentingan terbaik bagi anak menghendaki sanksi perampasan kemerdekaan sebagai upaya terakhir agar tidak mengebiri masa depan anak dan berpihak pada kepentingan terbaiknya. Oleh karena itu, asas kepentingan terbaik bagi anak semestinya menjadi pertimbangan dalam penyelesaian perkara anak yang berkonflik dengan hukum. Dalam artikel ini, putusan Pengadilan Tinggi Tanjung Karang dijadikan sebagai bahan pembahasan untuk melihat apakah fungsionalisasi asas kepentingan terbaik bagi anak yang berkonflik dengan hukum telah diterapkan, 
dan bagaimana pula implikasi dari penerapan tersebut.

Anak merupakan anugerah Tuhan Yang Maha Esa, sekaligus generasi penerus bangsa yang tidak terpisahkan dari keberlangsungan hidup manusia dan sebuah negara. ${ }^{1}$ Oleh karenanya, negara berkepentingan untuk menjamin dan menjunjung tinggi hak dan martabat setiap anak. Namun demikian, anak juga dalam perkembangan masyarakat kerap dihadapkan pada persoalan hukum. Dalam penemuan jatidirinya, acap kali anak tidak menyadari perbuatan yang dilakukannya bertentangan dengan hukum, sehingga mereka harus berhadapan dengan peradilan pidana baik sebagai pelaku utama maupun turut serta melakukan tindak pidana. ${ }^{2}$ Komisi Perlindungan Anak Indonesia (KPAI) menyebutkan, sepanjang tahun 2018 terdapat 1.434 kasus anak yang berhadapan dengan hukum. ${ }^{3}$

Agar keberlangsungan hidup, tumbuh, dan kembang anak tidak terganggu, diperlukan perlindungan khusus bagi anak yang berkonflik dengan hukum. Perlindungan anak merupakan usaha untuk mewujudkan pertumbuhan dan perkembangan anak secara wajar baik fisik, mental, maupun sosial. Perlindungan anak harus dilakukan dalam berbagai aspek kehidupan bernegara dan bermasyarakat, karena perlindungan anak merupakan manifestasi keadilan dalam masyarakat. ${ }^{4}$ Salah satu komitmen negara dalam memberikan perlindungan anak yakni dengan diratifikasinya Konvensi Hakhak Anak oleh Pemerintah Indonesia melalui Keputusan Presiden Nomor 36 Tahun 1990. Konvensi ini pada intinya memuat prinsipprinsip umum perlindungan anak yang meliputi non diskriminasi, kepentingan terbaik bagi anak, kelangsungan hidup dan tumbuh

1 Rifki Septiawan Ibrahim dan Dientje Rumimpunu, "Hak-Hak Keperdataan Anak dalam Perspektif Undang-Undang Nomor 35 Tahun 2014 tentang Perlindungan Anak", Lex Privatum, 6, 2 (2018), hlm. 53.

2 Olvina Kartika Mamentu, "Peran Pasal 2 Undang-Undang Nomor 11 Tahun 2012 tentang Sistem Peradilan Pidana Anak terhadap Anak yang Berkonflik dengan Hukum”, Lex Crimen, 4, 2 (2015), hlm. 140.

3 Nyi R. Irmayani, "Problematika Penanganan terhadap Anak Pelaku Tindak Kekerasan Seksual Selama Menjalankan Proses Hukum: Kasus di Provinsi Kalimantan Barat”, Sosio Konsepsia, 8, 3 (2019), hlm. 288.

4 Maidin Gultom, Perlindungan Hukum terhadap Anak dalam Sistem Peradilan Pidana Anak di Indonesia (Bandung: PT. Refika Aditama, 2008), hlm. 3. 
kembang anak, serta penghargaan atas partisipasi anak. Upaya Pemerintah Indonesia dalam melindungi anak semakin terlihat keseriusannya dengan dibentuknya Undang-Undang Nomor 11 tahun 2012 tentang Sistem Peradilan Pidana Anak.

Undang-Undang Nomor 11 Tahun 2012 tentang Sistem Peradilan Pidana Anak (UU SPPA) membawa perubahan fundamental terhadap sistem peradilan anak di Indonesia. Hal ini dapat dilihat dari diadopsinya asas kepentingan terbaik bagi anak pada proses penyelesaian perkara anak yang berkonflik dengan hukum. Asas tersebut secara tegas dinyatakan dalam Pasal 2 huruf d UU SPPA. Dengan dianutnya asas kepentingan terbaik bagi anak, maka pidana menjadi obat terakhir (ultimum remedium). Sebelum masuk ke rana pidana, harus ada upaya lain terlebih dahulu, yaitu melalui proses diversi. UU ini memberi harapan pada penghindaran stigma buruk peradilan pidana bagi anak, dikarenakan penyelesaian perkara berorientasi pada pemulihan dan bukan pembalasan. Sekalipun penyelesaian perkara anak harus sampai pada proses peradilan pidana, Pasal 71 UU SPPA memberikan banyak opsi bagi hakim dalam menjatuhkan pidana. Asas kepentingan terbaik bagi anak membatasi kebebasan hakim dalam menjatuhkan putusan, sebab hakim dalam memeriksa perkara anak tidak hanya melihat perbuatan anak dari aspek formil saja, melainkan juga harus mempertimbangkan keadaan pribadi anak serta motif dalam melakukan tindak pidana sehingga putusan hakim diharapkan dapat menyentuh aspek kemanusiaan anak dan sesuai dengan asas kepentingan terbaik bagi anak.

Salah satu contoh penerapan asas kepentingan terbaik bagi anak yang berkonflik dengan hukum adalah Putusan Mahkamah Agung Nomor: 125/pid/a/2012/pn.gs. Dalam putusan ini, hakim menjatuhkan hukuman tindakan pengembalian kepada orang tua terhadap anak WHD (15 tahun) yang terjerat kasus pencurian dengan pemberatan. Dalam artikel ini akan dilihat, apakah model pemeriksaan dan putusan perkara yang demikian itu diikuti dalam putusan lainnya, dalam hal ini putusan Pengadilan Tinggi Tanjung Karang. Dalam rentang tahun 2011-2016, pada Pengadilan Tinggi Tanjung Karang terdapat 22 perkara anak yang berkonflik dengan 
hukum.

Dalam membahas fungsionalisasi asas kepentingan terbaik bagi anak yang berkonflik dengan hukum, artikel ini setelah ini akan membahas asas ultimum remedium dan asas kepentingan terbaik bagi anak. Pembahasan ini diperlukan untuk mengetahui dasar teoretis dalam menjatuhkan hukuman kepada anak yang berkonflik dengan hukum. Bagian berikutnya membahas fungsionalisasi asas kepentingan terbaik bagi anak yang berkonflik dengan hukum pada putusan Pengadilan Tinggi Tanjung Karang, dan implikasi dari penerapannya. Dari 22 perkara anak yang berkonflik dengan hukum, empat di antaranya dibahas secara lebih mendalam, dan 18 hanya dilihat putusannya. Artikel diakhiri dengan penyimpulan dan penyampaian referensi rujukan.

\section{B. Asas Ultimum Remedium dan Asas Kepentingan Terbaik Bagi Anak}

Asas hukum merupakan prinsip hukum yang abstrak dan melatarbelakangi peraturan konkret dan implementasi hukum. Apabila terdapat kontradiksi dalam sistem hukum, maka asas hukum hadir untuk mengatasi kontradiksi tersebut. ${ }^{5}$ Berkaitan dengan bahasan dalam penelitian ini, asas ultimum remedium dan asas kepentingan terbaik bagi anak digunakan sebagai dasar teoritis dalam mengkaji pokok bahasan. Penggunaan asas hukum tersebut dikarenakan dalam melakukan rekayasa sosial, asas hukum dapat dijadikan dasar untuk mewujudkan pembangunan hukum nasional yang dinamis dan kondusif. ${ }^{6}$

Sebagai alat kontrol sosial, penggunaan hukum pidana bersifat subsidair. Dengan kata lain, hukum pidana digunakan ketika upayaupaya lain tidak memadai. ${ }^{7}$ Menurut Van Bemmelen, ancaman

5 Marwan Mas, Pengantar Ilmu Hukum (Jakarta: Ghalia, 2004), hlm. 99.

6 Beby Suryani Fithri, "Asas Ultimum Remedium terhadap Anak yang Berkonflik dengan Hukum dalam Rangka Perlindungan Anak”, Jurnal Mercatoria, 10, 1 (2017), hlm. 82.

7 Mohammad Ekaputra, Dasar-Dasar Hukum Pidana (Medan: USU Press, 2010), hlm. 13. 
penderitan yang diberikan hukum pidana membedakan hukum pidana dengan bidang hukum lain. Perbedaan demikian itulah yang menjadi alasan bahwa hukum pidana sebagai obat terakhir atau ultimum remedium. ${ }^{8}$ Sudikno Mertokusumo mengartikan ultimum remedium sebagai alat terakhir. ${ }^{9}$ Ini artinya, sanksi pidana baru digunakan apabila sanksi lain tidak mempan ataupun tidak mampu menyelesaikan konflik. Asas ultimum remedium bukan asas konstitusional, namun sekadar etika legislatif pada tahapan kriminalisasi. ${ }^{10}$ Asas ultimum remedium mengandung tujuan agar sanksi pidana dijatuhkan pada orang yang tepat, karena menyangkut hak asasi manusia seseorang. Diadopsinya asas ultimum remedium dalam sistem hukum Indonesia khususnya hukum pidana, merepresentasikan babak baru hukum pidana Indonesia. Pencapaian keadilan beorientasi pada perbaikan dan pemulihan keadaan yang dikenal dengan restorative justice. Berbeda dengan keadilan retributif yang menekankan pembalasan, oleh sebab itu pidana sebagai ultimum remedium. ${ }^{11}$

Penjatuhan pidana terhadap anak harus bersifat ultimum remedium, yang berarti penjatuhan pidana terhadap anak yang berkonflik dengan hukum adalah upaya terakhir setelah tidak ada lagi upaya hukum lain yang menguntungkan bagi anak. Selain itu, penjatuhan pidana terhadap anak harus bertujuan untuk perbaikan dan menekan angka kejahatan oleh anak dan mengutamakan kepentingan terbaik bagi anak. Penerapan asas ultimum remedium dilakukan melalui sistem peradilan pidana anak yang telah diatur secara implisit dalam UUSPPA. Walaupun tidak ditemukan secara tegas dalam ketentuan UU tersebut mengenai ultimum remedium, asas ini sesungguhnya menjiwai konsep diversi yang tersirat dalam Pasal 2, yang pada intinya menyatakan bahwa anak tidak dapat dirampas kemerdekaannya

8 Zainal Abidin Farid, Hukum Pidana I (Jakarta: Sinar Grafika, 2007), hlm. 13.

9 Sudikno Mertokusumo, Penemuan Hukum Sebuah Pengantar (Jakarta: Liberty, 2009), hlm. 128.

10 Fithri, "Asas Ultimum Remedium terhadap Anak, hlm. 83.

11 Novita Sari, "Penerapan Asas Ultimum Remedium dalam Penegakan Hukum Tindak Pidana Penyalahgunaan Narkotika”, Jurnal Penelitian Hukum De Jure, 17, 3 (2017), hlm. 353. 
kecuali terpaksa. Memang tidak semua tindak pidana yang dilakukan anak dapat diselesaikan diluar peradilan pidana, aplikasi asas ultimum remedium terhadap anak yang berkonflik dengan hukum hanya dapat dilakukan terhadap tindak pidana yang ancaman hukumannya di bawah tujuh tahun dan bukan pengulangan. Namun, pidana penjara bukanlah yang utama. Dalam Pasal 71 ayat (1) UUSPPA disebutkan, pidana penjara terletak pada kasta terbawah dari pidana pokok. ${ }^{12}$ Ini artinya, masih ada opsi hukuman lain yang lebih menguntungkan dan berpihak pada kemanusiaan anak.

Penerapan asas ultimum remedium terhadap anak yang berkonflik dengan hukum penting untuk memberikan perlindungan kepada anak sekaligus mencari solusi dari masalah yang timbul akibat penjatuhan sanksi. Fakta menunjukkan bahwa saat ini Lembaga Pemasyarakatan di Indonesia mengalami overload, bahkan belum semua wilayah di Indonesia mempunyai Lembaga Pemasyarakatan khusus anak. Oleh karena itu, asas ultimum remedium hendaknya dijadikan pedoman oleh hakim dalam menjatuhkan putusannya sebagimana yang pernah dilakukan oleh hakim agung dalam memutus perkara anak WHD (15 tahun) yang dikenai sanksi tindakan pengembalian kepada orangtuanya. Selain itu putusan hakim terebut selaras dengan asas kepentingan terbaik bagi anak.

Penyelesaian perkara anak harus berdasarkan asas kepentingan terbaik bagi anak. Asas ini pada intinya menghendaki proses peradilan formal terhadap anak merupakan upaya terkahir (ultimum remedium). ${ }^{13}$ Asas kepentingan terbaik bagi anak merupakan tindak lanjut dari amanah Pasal 28B Ayat (2) UUD RI Tahun 1945. Selain itu, asas ini dinyatakan dalam Pasal 2 huruf d UU SPPA. Dalam penjelasan umum pasal 2 huruf b UU SPPA disebutkan, yang dimaksud dengan kepentingan terbaik bagi anak adalah segala pengambilan keputusan harus selalu mempertimbangkan kelangsungan hidup

12 Pasal 71 ayat (1) UU SPPA menentukan pidana pokok bagi anak terdiri atas: pidana peringatan, pidana dengan syarat, pelatihan kerja, pembinaan dalam lembaga, dan penjara.

13 Y. A Triana Ohoiwutun dan Samsudi, "Penerapan Prinsip Kepentingan Terbaik Bagi Anak dalam Kasus Tindak Pidana Narkotika Kajian Putusan Nomor 229/Pid.B/2012/ PN.Jpr”, Jurnal Yudisial, 10, 1 (2017), hlm. 47. 
dan tumbuh kembang anak. Kepentingan terbaik bagi anak harus dihayati sebagai kepentingan terbaik bagi masyarakat, nusa dan bangsa. Konstitusi menyatakan bahwa negara menjamin hak setiap anak atas kelangsungan hidup, tumbuh dan berkembang serta atas perlindungan dari tindak kekerasan dan perlakuan diskriminasi. Asas kepentingan terbaik bagi anak harus diletakkan pada garda terdepan dalam proses penyelesaian perkara anak yang berkonflik dengan hukum. Hal ini diperlukan agar anak dapat menyongsong masa depannya dan memberikan kesempatan bagi anak untuk menjadi manusia yang berguna dan bertanggungjawab.

Berdasarkan ketentuan Pasal 1 angka 11 KUHAP, putusan pengadilan adalah pernyataan hakim yang ditetapkan dalam sidang terbuka yang dapat berupa pemidanaan, lepas dari tuntutan hukum dan bebas. Hakim sebagai wakil Tuhan di dunia mempunyai peran penting dalam memberikan keadilan bagi anak. Dalam memutus perkara anak yang berkonflik dengan hukum, hakim tidak hanya mengacu pada ketentuan formal saja melainkan harus mengedepankan kepentingan terbaik bagi anak. Putusan hakim yang mengandung pemidanaan tentu akan menimbulkan konsekuensi tersendiri bagi anak dan bertentangan dengan tujuan pemidanaan yang integratif. Sebagaimana yang dikemukan oleh Muladi dan Ohoiwutun, pemidanaan harus bersifat integratif yaitu perlindungan masyarakat; memelihara solidaritas masyarakat; pencegahan; dan pengimbalan atau pengimbangan. ${ }^{14}$

Penerapan asaskepentinganterbaikbagianak dalampenyelesaian perkara anak yang berkonflik dengan hukum merupakan salah satu bentuk perlindungan anak. Perilaku dursila atau kenakalan anak adalah gejala sakit sosial pada anak. Kenakalan anak biasa juga disebut junevile deliquency. ${ }^{15}$ Paul Moedikno menyatakan bahwa junevile deliquency itu adalah: 1) semua perbuatan yang apabila dilakukan

14 Y. A Triana Ohoiwutun, "Urgensi Bedah Mayat Forensik dalam Pembuktian Tindak Pidana Pembunuhan Berencana: Kajian Putusan Nomor 79/ Pid.B/2012/PN.BGR”, Jurnal Yudisial, 10, 1 (2017), hlm. 60.

15 Kartini Kartono, Patologi Sosial 2 Kenakalan Remaja (Jakarta: Rajawali Press, 1992), hlm. 7. 
oleh orang dewasa merupakan kejahatan, namun apabila dilakukan oleh anak-anak merupakan deliquency; 2) semua perbuatan yang bertentangan dengan norma kelompok tertentu dalam masyarakat yang mengganggu ketertiban dalam masyarakat, dan 3) semua perbuatan yang membutuhkan perlindungan sosial. ${ }^{16}$

Penyelesaian perkara anak yang berkonflik dengan hukum dengan didasari asas kepentingan terbaik bagi anak juga sejalan dengan asas parens patriae. Hal ini berarti apabila anak membutuhkan pertolongan maka penguasa harus bertindak, sedangkan anak yang melakukan kejahatan bukannya dipidana, melainkan harus diberi bantuan dan diberikan perlindungan. ${ }^{17}$

\section{Fungsionalisasi Asas Kepentingan Terbaik bagi Anak yang Berkonflik dengan Hukum pada Pengadilan Tinggi Tanjung Karang}

Hukum pidana berfungsi untuk melindungi kepentingan hukum terhadap perbuatan yang hendak memperkosanya. Sanksi pidana itu mengandung penderitaan yang menyedihkan, oleh karenanya hukum pidana harus dioperasional dengan hati-hati. Hukum pidana merupakan obat yang terakhir (ultimum remedium) bukan obat yang utama (premium remedium). Mengingat anak adalah generasi penerus bangsa yang harus dilindungi karena masa depannya yang masih panjang, sedapat mungkin anak dihindarkan dari sanksi pidana. Sebagaimana ketentuan Pasal 28b UUD 1945 yang menyatakan bahwa negara menjamin perlindungan hak-hak anak atas keberlangsungan hidupnya, tumbuh dan berkembang dan perlakuan diskriminasi. ${ }^{18}$ Hal ini sejalan dengan Pasal 66 ayat (5) Undang-Undang Nomor 39 Tahun 1999 tentang Hak Asasi Manusia (UU HAM) ${ }^{19}$ dan Pasal 16 ayat

16 Romli Atmasasmita, Problem Kenakalan Anak-Anak Remaja (Bandung: Amico, 1983), hlm. 22.

17 Tongat, Dasar-Dasar Hukum Pidana di Indonesia dalam Perspektif Pembaharuan (Malang: UMM Press, 2009), hlm. 31.

18 Ahmad Syakirin, "Formulasi/Model Sistem Pemidanaan Anak di Indonesia", Mimbar Yustitia, 2, 2 (2018), hlm. 124.

19 Pasal 66 ayat (5) Undang-Undang Nomor 39 Tahun 1999 menentukan setiap anak yang dirampas kembebasannya berhak mendapat perlakuan 
(3) Undang-Undang Nomor 23 Tahun 2002 tentang Perlindungan Anak (UUPA), yang pada intinya menyatakan bahwa pidana penjara hanya dapat dilakukan sebagai upaya terakhir. ${ }^{20}$ Demikian pula yang ditentukan dalam Pasal 2 UU SPPA yang menyatakan bahwa pada dasarnya anak tidak dapat dirampas kemerdekaannya kecuali terpaksa. Filosofinya adalah untuk mencegah stigmatisasi terhadap anak.

Pasal 71 UU SPPA menyediakan banyak pilihan bagi hakim dalam memberikan putusan, mulai dari pidana peringatan, pembinaan diluar lembaga, pelayanan masyarakat, pengawasan, pelatihan kerja, pembinaan dalam lembaga, penjara, perampasan keuntungan, dan pemenuhan kewajiban adat.Ketentuan Pasal 71 UU SPPA tersebut sejalan dengan filosofi dasar perlakuan terhadap anak nakal, yakni untuk kepentingan terbaik anak. Namun akhir-akhir ini masyarakat begitu mudah menghakimi pelaku tindak pidana tanpa pandang bulu, tidak peduli apakah pelaku sudah dewasa atau masih anakanak. ${ }^{21}$ Bahkan bagi anak-anak yang perkaranya terlanjur diperiksa oleh pengadilan, aparat penegak hukum khususnya hakim seringkali tidak memperhatikan hak dan kondisi kejiwaan anak. ${ }^{22}$ Berdasarkan penelitian di Pengadilan Tinggi Tanjung Karang, sejak tahun 2011 hingga 2016, terdapat 22 perkara anak yang ditangani oleh Pengadilan Tinggi Tanjung Karang. Dari 22 perkara anak tersebut, sebanyak 16 perkara mengandung vonis berupa pidana penjara, enam perkara telah berkekuatan hukum tetap, sebagaimana terlihat pada tabel 1 .

secara manusiawi dan dengan memperhatikan kebutuhan pengembangan pribadi sesuai dengan usianya dan harus dipisahkan dari orang dewasa, kecuali demi kepentingannya.

20 Pasal 16 ayat (3) UUPA menentukan penangkapan, penahanan, atau tindak pidana penjara anak hanya dilakukan apabila sesuai dengan hukum yang berlaku dan hanya dapat dilakukan sebagai upaya terakhir.

21 Syachdin, "Application of The Ultimum Remedium Principle to The Children Involved in Narcotic", Tadulako Law Review, 1, 2 (2016), hlm. 200.

22 Dheny Wahyudi, "Perlindungan terhadap Anak yang Berhadapan dengan Hukum Melalui Pendekatan Restorative Justice”, Jurnal Ilmu Hukum, 6, 1 (2015), hlm. 145. 


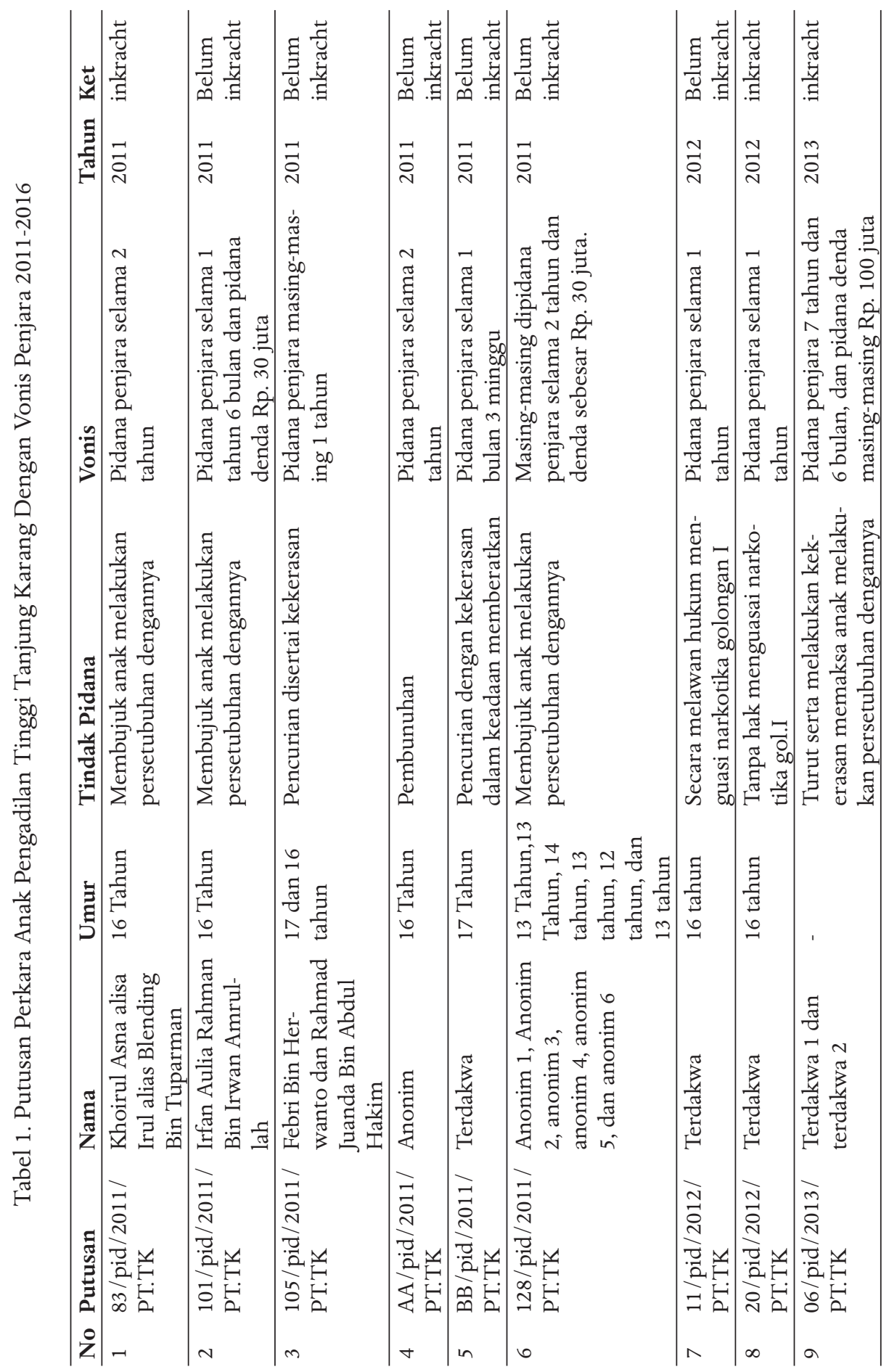




\begin{tabular}{|c|c|c|c|c|c|c|}
\hline 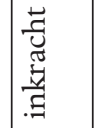 & 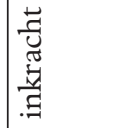 & 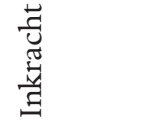 & 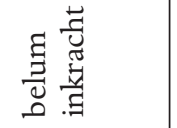 & 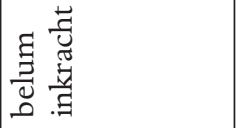 & 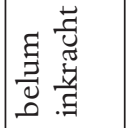 & 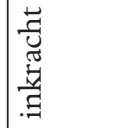 \\
\hline${ }^{\circ}$ & 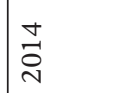 & $\stackrel{n}{\stackrel{n}{\sim}}$ & $\stackrel{\circ}{\stackrel{\sim}{N}}$ & $\stackrel{\circ}{\stackrel{\sim}{N}}$ & 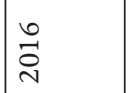 & 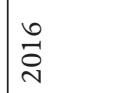 \\
\hline 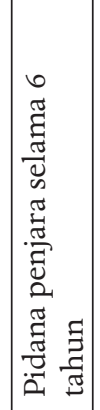 & 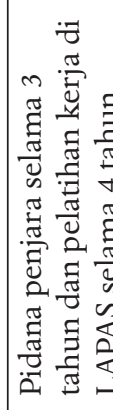 & 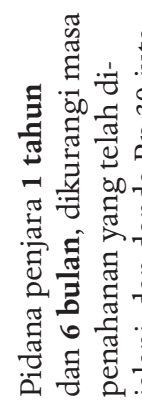 & 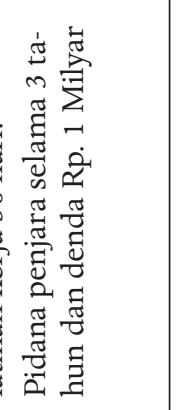 & 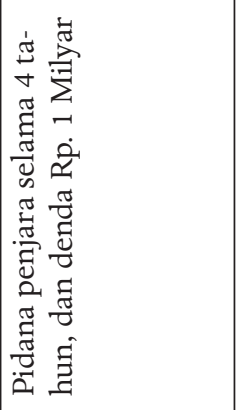 & 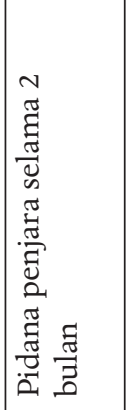 & 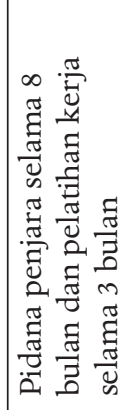 \\
\hline 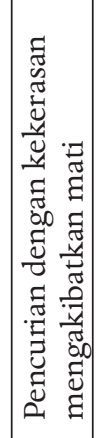 & 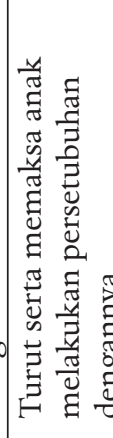 & 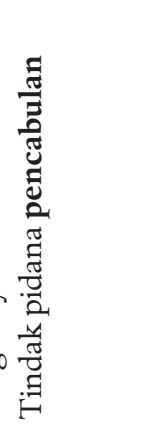 & 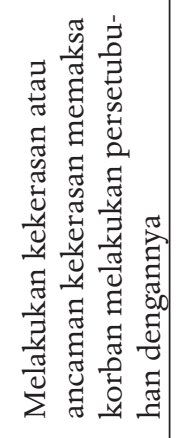 & 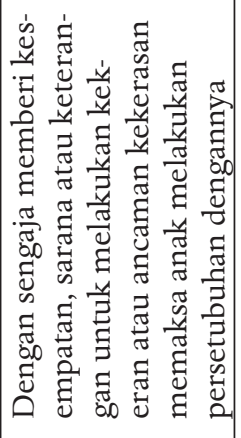 & 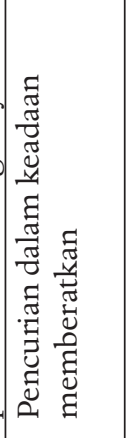 & 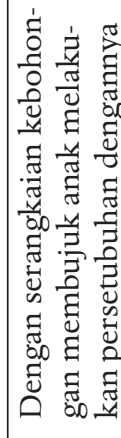 \\
\hline & 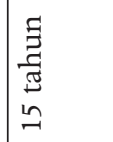 & , & 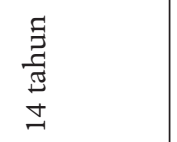 & 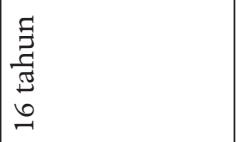 & 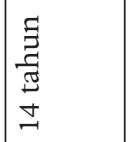 & 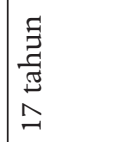 \\
\hline & 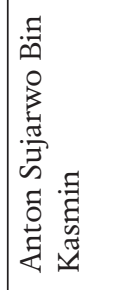 & 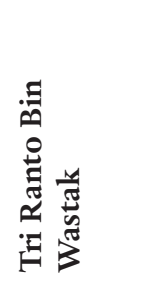 & 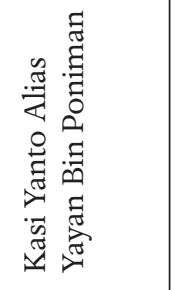 & 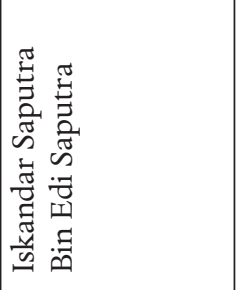 & 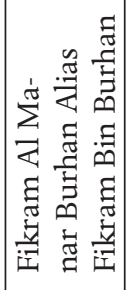 & 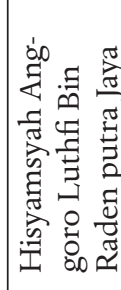 \\
\hline 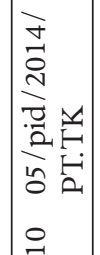 & 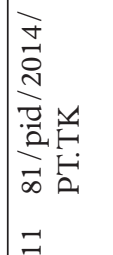 & 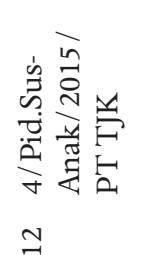 & 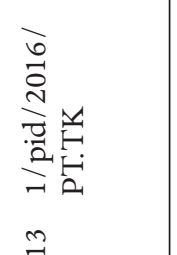 & 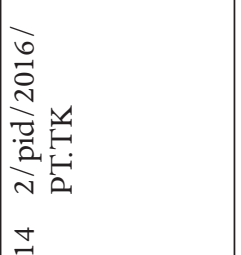 & 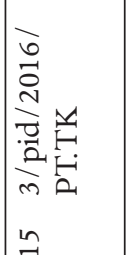 & 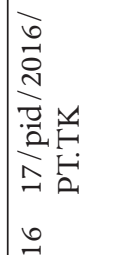 \\
\hline
\end{tabular}


Tabel 1 memberikan gambaran bahwa asas kepentingan terbaik bagi anak belum diterapkan secara optimal oleh hakim pada Pengadilan Tinggi Tanjung Karang. Dalam putusan Nomor 05/ $\mathrm{Pid} / 2014$ /PT.TJK misalnya, hakim menjatuhkan hukuman pidana penjara selama enam tahun karena terdakwa terbukti melakukan tindak pidana pencurian dengan kekerasan mengakibatkan kematian. Dalam pertimbangannya, hakim menyatakan terdakwa menghendaki motor korban dan kematian korban menjadi tujuan terdakwa. Oleh karena itu, hakim berpendapat bahwa penjatuhan pidana ringan jelas tidak akan memberikan efek jera bagi terdakwa dan tidak memberikan pelajaran hukum bagi masyarakat lainnya. Dalam putusan tersebut, hakim tidak mempertimbangkan sisi lain dari terdakwa yang masih muda dan masih ada harapan untuk dibina serta masih ingin melanjutkan sekolah, sebagaimana tercantum dalam pembelaan terakwa. Selain itu, hakim tidak mempertimbangkan asas kepentingan terbaik bagi anak sebagaimana ketentuan Pasal 2 huruf d UU SPPA. Dalam memutus perkara ini, hakim tidak mempertimbangkan hak anak untuk memperoleh rehabilitasi sosial, sebagaimana ketentuan Pasal 90 ayat (1) huruf a UU SPPA.

Demikian juga dalam putusan Nomor: 20/Pid/2012/PT.TK, hakim menjatuhkan putusan berupa pidana penjara selama satu tahun kepada terdakwa (16 tahun). Dalam perkara ini, terdakwa terbukti tanpa hak menguasai narkotika golongan satu. Hakim dalam pertimbangannya berpendapat bahwa penyalahgunaan narkotika secara melawan hukum dapat merusak kesehatan pemakainya dan membahayakan kehidupan masyarakat. Oleh karena itu, penegak hukum berkomitmen untuk memberantas tindak pidana narkotika salah satunya dengan menjatuhkan pidana penjara yang berat kepada pelaku. Namun demikian, hakim berpendapat bahwa upaya pemberantasan narkotika dengan penjatuhan pidana penjara tidak boleh digeneralisasi melainkan harus dilihat secara kasuistis. Hakim telah mempertimbangkan kepentingan terbaik bagi anak sebagaimana dimaksud dalam Pasal 2 butir b UUPA. Selain itu, menurut hakim penyelesaian perkara anak ini selayaknya didasarkan pada semangat keadilan restoratif yang mengedepankan pemulihan 
pada keadaan semula, dan bukan dengan pidana penjara sebagai pembalasan. Namun demikian, hakim tetap menjatuhkan pidana penjara dan telah mengabaikan tindakan rehabilitasi medis dan rehabilitasi sosial terhadap terdakwa yang sekaligus merupakan korban penyalahgunaan narkotika.

Dua perkara ini setidaknya cukup menggambarkan bahwa pertimbangan hakim dalam memvonis pidana pada perkara anak yang berkonflik dengan hukum pada Pengadilan Tinggi Tanjung Karang sebagian besar didasarkan pada pertimbangan yuridis yang berbasis pada asas legalitas semata. Hakim belum sepenuhnya mempertimbangkan ketentuan non-yuridis khususnya kondisi anak yang masih muda dan masih mempunyai harapan. Utrecht mengemukakan beberapa keberatan terhadap asas legalitas, yakni asas legalitas kurang melindungi kepentingan umum, perbuatan yang dapat dihukum hanyalah perbuatan yang diatur sebagai tindak pidana oleh hukum. Ada kemungkinan seseorang melakukan kejahatan, namun hukum tidak mengaturnya sebagai perbuatan yang melanggar ketertiban umum, dan asas legalitas menjadi penghalang bagi hakim untuk menghukum pelakunya. ${ }^{23}$ Dengan tidak dilakukannya rehabilitasi medis dan rehabilitasi sosial terhadap anak yang berkonflik dengan hukum, secara tidak langsung telah mengesampingkan asas kepentingan terbaik bagi anak. Sebab, anak bagaimanapun merupakan tunas muda yang masih mempunyai berbagai keterbatasan dibanding orang dewasa. ${ }^{24}$ Selain itu, anak mempunyai peran strategis untuk melanjutkan cita-cita bangsa Indonesia. Oleh karena itu, penjatuhan pidana penjara terhadap anak yang berkonflik dengan hukum tanpa disertai tindakan rehabilitasi akan menimbulkan stigma negatif dan menghambat perkembangan anak. ${ }^{25}$ Hal demikian sekaligus memperlihatkan praktik peradilan

23 Kamaruddin Jafar, "Restorative Justice atas Diversi dalam Penanganan Juvenile Deliquency (Anak Berkonflik Hukum)”, Al-Adl, 8, 2 (2015), hlm. 86-87.

24 Afni Zahra dan RB. Sularto, "Penerapan Asas Ultimum Remedium dalam Rangka Perlindungan Anak Pecandu Narkotika”, Law Reform, 13, 1 (2017), hlm. 19.

25 Zahra dan Sularto, "Penerapan Asas Ultimum Remedium”, hlm. 50. 
anak dirasa belum mencerminkan tujuan hukum secara filosofi, yakni kesejahteraan. ${ }^{26}$ Pengadilan anak harus mengedepankan kesejahteraan anak dengan menempatkan anak sebagai sumber daya manusia yang harus dilindungi dari kondisi yang merugikannya. ${ }^{27}$

Jika yang demikian itu merupakan gambaran dari 16 perkara yang divonis penjara, sekarang bagaimana dengan perkara selebihnya. Pada bagian sebelumnya disampaikan, dalam rentang 2011-2016 terdapat 22 perkara anak pada Pengadilan Tinggi Tanjung Karang. Ini berarti, sisa 16 yang divonis penjara, yaitu enam perkara, divonis bukan penjara. Enam perkara yang tidak divonis penjara ini diuraikan pada tabel 2 .

Tabel 2 menunjukkan bahwa dari enam perkara yang divonis bukan penjara, tiga di antaranya telah berkekuatan hukum tetap (inkracht). Dari enam putusan tersebut, dua di antaranya dapat dikatakan telah mempertimbangkan asas kepentingan terbaik bagi anak, yakni putusan nomor 10/Pid.2012/PT.TK dan putusan nomor 19/ PID/2013/PT.TK. Dalam putusan nomor 10/Pid.2012/PT.TK, terdakwa anak yang berusia 14 Tahun dinyatakan terbukti secara sah dan meyakinkan melakukan pencurian dalam keluarga. Akibat perbuatannya, terdakwa dikenakan tindakan berupa penyerahan kepada negara, untuk mengikuti pendidikan, pembinaan dan latihan kerja pada Lembaga Pemasyarakatan Anak Kota Bumi, Lampung, terhitung sejak yang bersangkutan mulai ditempatkan sampai dengan terdakwa anak tersebut berusia 18 tahun atau menjadi dewasa. Dalam

26 Bambang Sukoco, "Prospek dan Dilema Penerapan Restoratif Justice System dalam Kasus Pidana Anak”, Jurnal Ilmu Hukum, 14, 2 (2011), hlm. 344. Sudarto pernah mengingatkan, masalah sentral yang utama dalam konteks penanggulangan kenakalan anak meliputi empat hal pertama, penggunaan hukum pidana anak harus bertujuan untuk menangulangi kenakalan anak demi kesejahteraan anak; kedua, perbuatan anak yang akan dicegah atau ditanggulangi tersebut harus merupakan perbuatan yang menimbulkan kerugian materiil bagi anak maupun masyarakat; ketiga, penggunaan hukum pidana anak harus memperhitungkan prinsip biaya dan hasil; keempat, penggunaan hukum pidana anak harus memperhatikan kapasitas penegak hukum. Sudarto, Hukum Pidana I (Semarang: Yayasan Sudarto, 1990), hlm. 51-51.

27 Suparmin, "Kebijakan Hukum Pidana dalam Tindak Pidana yang Dilakukan Anak”, Qistie: Jurnal Ilmu Hukum, 1, 1 (2008). 


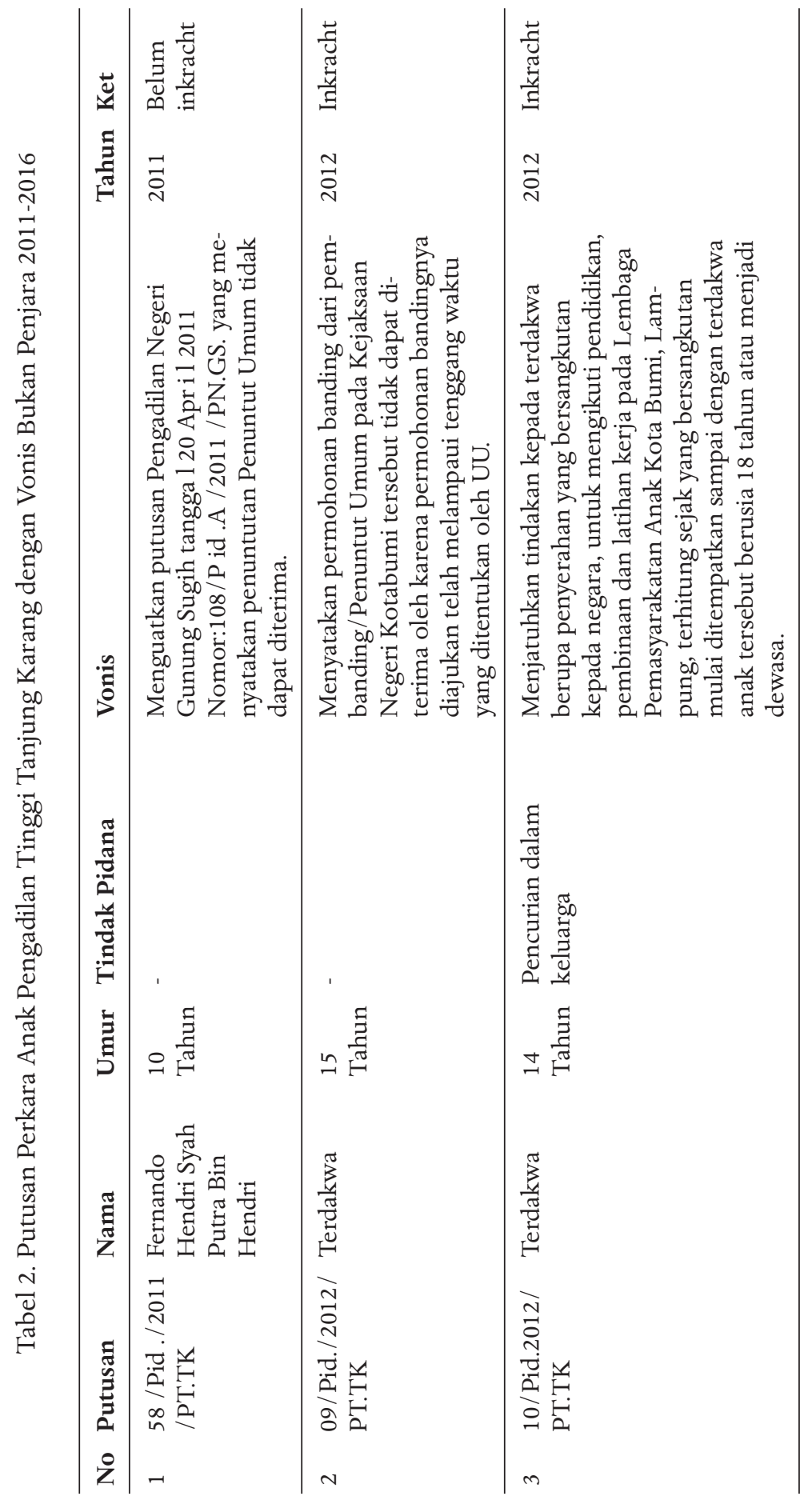


Fungsionalisasi dan Implikasi Asas Kepentingan Terbaik bagi Anak

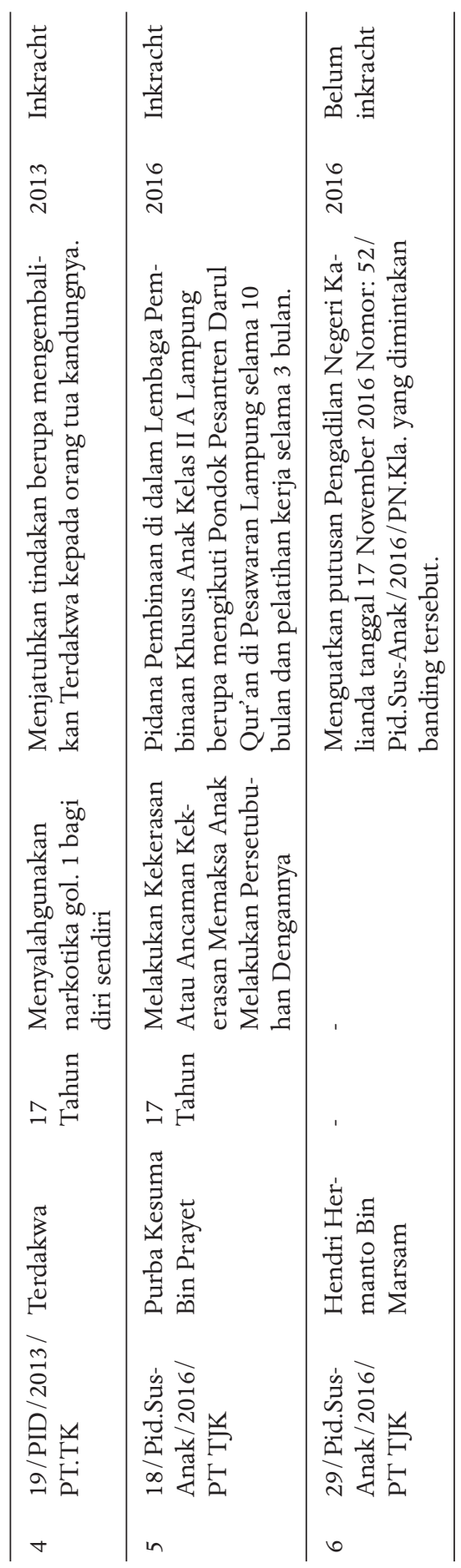


putusannya, hakim berpendapat bahwa perilaku terdakwa telah menyimpang dari norma kesusilaan, agama, dan hukum. Oleh karena itu, diperlukan pendidikan dan pembinaan yang komprehsif bagi anak tersebut. Dengan alasan tersebut, maka tepat apabila Terdakwa dijadikan anak negara. Dalam kapasitas sebagai anak negara, ada jaminan pendidikan, pembinaan maupun latihan kerja oleh negara di mana kegiatan tersebut secara berkelanjutan dan terarah guna menjamin pertumbuhan dan perkembangan anak, baik fisik, mental, spiritual maupun sosial. Tindakan ini dimaksudkan untuk mewujudkan kehidupan terbaik bagi anak sebagai generasi penerus bangsa. Hal ini juga sesuai asas perlindungan anak, sebagaimana disebutkan dalam pasal 2 point $\mathrm{b}$ maupun pasal 4 UU PA. ${ }^{28}$

Asas kepentingan terbaik bagi anak juga ditemukan dalam putusan nomor 19/PID/2013/PT.TK. Dalam putusan ini, terdakwa anak yang berusia 17 Tahun terbukti secara sah dan meyakinkan menyalahgunakan narkotika golongan satu bagi diri sendiri. Akibat perbuatannya, hakim menjatuhkan tindakan berupa mengembalikan Terdakwa kepada orang tua kandungnya (Manadi dan Sumiyana). Dalam pertimbangannya, hakim berpendapat bahwa pada satu sisi Terdakwa adalah pelaku tindak pidana yang dimintai pertanggungan jawab pidana, namun di sisi lain juga sebagai korban atau objek dalam proses peradilan pidana anak. Karena itu penanganan perkara ini harus mengacu pada asas perlindungan anak yaitu kepentingan yang terbaik bagi anak sebagaimana dimaksud dalam pasal 2 butir b UU PA. Berdasarkan penjelasan umum UU SPPA, kepentingan yang terbaik bagi anak merupakan semua tindakan yang menyangkut anak yang dilakukan oleh pemerintah, masyarakat, badan legislatif, badan yudikatif, dan kepentingan terbaik bagi anak harus menjadi pertimbangan utama. Terhadap alasan banding Penuntut Umum bahwa tindakan mengembalikan Terdakwa anak kepada orang tuanya dikhawatirkan tidak berefek jera dan hanya menjadikan anak sebagai

28 Pasal 2 huruf b UUPA menentukan penyelenggaraan perlindungan anak berasaskan Pancasila dan berlandaskan UUD RI Tahun 1945 serta prinsipprinsip dasar konvensi hak-hak anak yang meliputi kepentingan yang terbaik bagi anak. 
sarana penyalahgunaan narkotika oleh oleh orang dewasa, Hakim berpendapat pemidanaan terhadap pelaku tindak pidana anak tidak selalu harus dengan pendekatan penjara dengan tujuan efek jera. Kriminalisasi anak bukan satu-satunya cara yang dapat digunakan untuk menanggulangi penyalahgunaan narkotika.

Anak yang dijatuhi putusan pemidanaan di Pengadilan Tinggi Tanjung Karang masih berada pada usia produktif dengan rentang umur 12 sampai 17 tahun. Dalam pertimbangan hukum putusannya, kepentingan terbaik bagi anak belum sepenuhnya menjadi pertimbangan hakim dalam memutus perkara anak yang berkonflik dengan hukum. Dari total 22 perkara anak yang diadili oleh Pengadilan Tinggi Tanjung Karang, terdapat tiga perkara yang memuat asas kepentingan terbaik bagi anak dalam pertimbangan putusannya, yakni putusan nomor 20/Pid/2012/PT.TK, putusan nomor 10/Pid./2012/PT.TK, dan putusan nomor 19/PID/2013/ PT.TK. Dengan demikian, asas kepentingan terbaik bagi anak belum sepenuhnya menjiwai putusan hakim di Pengadilan Tinggi Tanjung Karang. Dalam pertimbangannya hakim cenderung pada ketentuan substantif tanpa melihat sisi lain dari anak yang berkonflik dengan hukum. Padahal asas kepentingan terbaik bagi anak telah tercermin dalam ketentuan sanksi yang dimuat dalam Pasal 71 UU SPPA, di mana sanksi berupa pidana penjara berada pada kasta terbawah dari pidana pokok. Sanksi lain yang lebih menguntungkan dan berpihak pada kepentingan terbaik anak adalah pidana peringatan, pembinaan di luar lembaga, pelayanan masyarakat, pengawasan, pelatihan kerja dan pembinaan dalam lembaga. Namun untuk menjatuhkan putusan itu, tentu hakim harus menggali keadaan pribadi anak, alasan anak melakukan perbuatan dan pengaruh diluar diri anak.

Mengingat banyaknya jumlah kasus anak yang dijatuhi putusan berupa pidana penjara, maka perlu ada solusi lain yang berpihak pada kepentingan terbaik bagi anak. Dengan penjatuhan sanksi pidana penjara belum tentu efektif dalam mengatasi permasalahan anak yang berkonflik dengan hukum. Selain itu, pidana perampasan kemerdekaan tentu akan menimbulkan masalah baru baik bagi anak maupun bagi pemerintah Indonesia. Sanksi tersebut dapat 
menimbulkan stigmatisasi anak, memasung masa depan anak dan menambah beban pemerintah mengingat Lembaga Pemasyarakatan saat ini mengalami overload. Ditambah lagi Lembaga Pemasyarakatan Khusus Anak (LPKA) masih minim.

Mencermati putusan Pengadilan Tinggi Tanjung Karang sebagaimana terlihat pada tabel 1, dengan banyaknya perkara anak berkonflik dengan hukum yang dijatuhi sanksi berupa pemidanaan seolah mengonfirmasi bahwa budaya hakim anak saat ini masih dipengaruhi oleh hukum kolonial yang hanya mengenal penghukuman sebagai penyelesaian masalah. Hal ini tentu sangat bertolak belakang dengan asas kepentingan terbaik bagi anak, penjatuhan sanksi pidana perampasan kemerdekaan tehadap anak sama sekali tidak mempertimbangkan kelangsungan hidup dan tumbuh kembang anak, apalagi sisi kemanusiaan anak.

Kelangsungan hidup dan perkembangan anak yang berhadapan dengan hukum merupakan masalah yang kompleks. Anak yang berkonflik dengan hukum memerlukan perlindungan mengingat anak ialah individu yang belum matang emosi dan cara berpikirnya, sebagaimana hakikat tujuan pengadilan anak yakni memberikan perlindungan dan menjamin kesejahteraan anak. Di sinilah asas kepentingan terbaik bagi anak harus dijadikan dasar pertimbangan bagi hakim dalam memberikan putusan pada anak yang berkonflik dengan hukum. Penjatuhan pidana penjara kepada mereka hanya akan membuat masa depan mereka suram, serta tidak memberikan jaminan perlindungan.

\section{Implikasi Penerapan Asas Kepentingan Terbaik bagi Anak yang Berkonflik dengan Hukum}

Sistem peradilan pidana anak pada hakikatnya mengedepankan perlindungan dan rehabilitasi terhadap anak pelaku tindak pidana. Hal ini dikarenakan anak merupakanorang yang masih mempunyai berbagai keterbatasan dibandingkan dengan orang dewasa. Oleh karena itu, terhadap anak yang melakukan tindak pidana diupayakan 
seminimal mungkin penjatuhan sanksi perampasan kemerdekaan. ${ }^{29}$ Dibanding dengan orang dewasa, anak memiliki banyak kekurangan baik fisik, mental dan sosial, dan karenanya penjatuhan pidana kepadanya diupayakan selain pidana penjara misalnya pidana tindakan dan sebagainya. Asas kepentingan terbaik bagi anak harus menjadi dasar pertimbangan bagi hakim dalam memutus perkara anak yang berkonflik dengan hukum. Selain pidana penjara, sejatinya anak yang berkonflik dengan hukum dapat dijatuhi sanksi yang lebih menguntungkan baginya, sebagaimana ketentuan Pasal 71 UU SPPA bahwa sanksi bagi anak terdiri dari pidana peringatan, pembinaan diluar lembaga, pelayanan masyarakat, pengawasan, pelatihan kerja dan pembinaan dalam lembaga, perampasan keuntungan dari tindak pidana dan pemenuhan kewajiban adat.

Sebagaimana diuraikan sebelumnya, bahwa penerapan asas kepentingan terbaik bagi anak pada Pengadilan Tinggi Tanjung Karang belum optimal. Dalam putusan Nomor: 05/Pid/2014/PT TJK, hakim menjatuhkan hukuman pidana penjara selama enam tahun, sedangkan pada putusan Nomor: 20 / Pid/ 2012/ PT.TK, hakim menjatuhkan putusan berupa pidana penjara selama satu tahun. Kedua putusan tersebut menggambarkan bahwa dalam memutus perkara anak, hakim pada Pengadilan Tinggi Tanjung Karang masih berorientasi pada pembalasan dan belum mengedepankan asas kepentingan terbaik bagi anak.

Penerapan asas kepentingan terbaik bagi anak yang berkonflik dengan hukum menimbulkan beberapa implikasi. Pertama, implikasi terhadap pembuat delik. Implikasi positif penerapan asas kepentingan terbaik bagi anak yang berkonflik dengan hukum yaitu memberikan perlindungan kepada anak; menghindarkan anak dari stigma buruk pemenjaraan; memberikan kesempatan pada anak untuk pemulihan psikologis; memberikan kesempatan pada anak untuk menyadari kesalahannya dan menjadi manusia berguna dan bertanggungjawab; menghindarkan anak dari label buruk di masyarakat, sehingga anak lebih muda bergaul dan diterima kembali di masyarakatnya;

29 Marlina, Pengantar Konsep Diversi dan Restoratif justice dalam Hukum Pidana (Medan: USU Press, 2010), hlm. 1. 
mencegah trauma berkepanjangan pada anak akibat pemenjaraan. Kedua, implikasi terhadap pelaksanaan kekuasaan kehakiman, yaitu: mengurangi beban perkara pengadilan dan meringankan beban Lembaga Pemasyarakatan yang kini overload dan mengurangi anggaran untuk pembinaan di Lembaga Pemasyarakatan.

Asas kepentingan terbaik bagi anak melahirkan norma hukum berupa pengaturan diversi sebagai wujud asas kepentingan terbaik bagi anak. ${ }^{30}$ Meskipun diversi memiliki banyak keuntungan dan berpihak terhadap kepentingan anak termasuk anak pelaku tindak pidana, menurut Lilik Mulyadi juga menimbulkan beberapa implikasi, yakni berpotensi melanggar hak anak, diversi melanggar hak anak atas praduga tak bersalah, diversi melanggar hak anak atas peradilan yang adil, dan adanya polarisasi pemikiran ambiguitas dan perlakuan diskriminatif khususnya bagi anak yang berkonflik dengan hukum. ${ }^{31}$

Di sisi lain, pada era globalisasi saat ini pembentukan karakter anak sangat dipengaruhi oleh lingkungannya, rekan bergaul maupun hal-hal yang didapat di dunia maya. Karena itu, tindak pidana yang dilakukan anak bisa saja memang dikehendaki. Sebagaimana diuraikan sebelumnya, dari 22 perkara anak yang berkonflik dengan hukum yang diadili oleh Pengadilan Tinggi Tanjung Karang, terdapat tiga perkara yang dalam pertimbangan putusannya dikategorikan memuat asas kepentingan terbaik bagi anak. Namun demikian, hal itu ternyata bukan berarti putusan berdampak pada pidana bukan penjara. Pada putusan nomor20/Pid/2012/PT.TK, hakim tetap memutus dengan pidana penjara. Sedangkan dua putusan lainnya, yakni putusan nomor 10/Pid./2012/PT.TK dan putusan nomor 19/ PID/2013/PT.TK., hakim memutus dengan pidana bukan penjara.

Penerapan asas kepentingan terbaik bagi anak juga memungkinkan timbulnya implikasi negatif. Pertama, bagi pembuat delik, dikhawatirkan tidak menimbulkan efek jera; adanya kemungkinan

30 Irzan Hafiandy, Madiasa Ablisar, Marlina, dan Mahmud Mulyadi, "Penerapan Asas Kepentingan Terbaik Bagi Anak dalam Pelaksanaan Diversi”, USU Law Journal, 6, 5 (2018), hlm. 60.

31 Teguh Prasetyo, "Penerapan Diversi terhadap Tindak Pidana Anak dalam Sistem Peradilan Pidana Anak", Refleksi Hukum: Jurnal Ilmu Hukum, 9, 1 (2015), hlm. 8. 
anak mengulangi perbuatannya; penerapan asas kepentingan terbaik bagi anak dapat memberikan peluang kepada pelaku kejahatan untuk menjadikan anak sebagai subyek kejahatan, mengingat ringannya ancaman sanksi bagi anak; penerapan asas kepentingan terbaik bagi anak dikhawatirkan mengundang reaksi negatif dan kecaman dari masyarakat, mengingat asas ini menghendaki sanksi yang paling menguntungkan dengan kata lain sanksi yang ringan. Hal ini tentu menimbulkan rasa tidak aman bagi anak untuk kembali bergaul di masyarakat.

Kedua, pelaksanaan kekuasaan kehakiman. Secara garis besar penerapan asas kepentingan terbaik bagi anak yang berkonflik dengan hukum dapat menimbulkan pemahaman dan reaksi negatif masyarakat terhadap penegakan hukum di Indonesia. Hal ini dikarenakan asas tersebut menghendaki hukuman yang seringan-ringannya bagi anak, sedangkan budaya hukum masyarakat seringkali merasa tidak puas apabila pelaku kejahatan tidak dipenjara.

Walaupun penanganan bagi anak-anak yang bermasalah dengan hukum telah diatur dengan berbagai perangkat hukum, hal demikian belum membawa perubahan yang cukup baik. ${ }^{32}$ Sebagaimana uraian sebelumnya, sebagian besar perkara anak yang diadili oleh Pengadilian Tinggi Tanjung Karang divonis pidana penjara. Pemenjaraan terhadap anak pelaku tindak pidana sudah pasti bertentangan dengan prinsip kepentingan terbaik bagi anak. Tidak diterapkannya asas kepentingan terbaik bagi anak setidaknya dapat menimbulkan beberapa implikasi dan dampak di antaranya, mengganggu psikologis anak, anak berisiko mengalami kekerasan, kebutuhan dasar tidak terpenuhi, tidak terpenuhinya hak untuk memperoleh pendidikan, anak menjadi kurang aktif, dan anak berisiko menjadi residivis. ${ }^{33}$

Berdasarkan uraian sebelumnya, dalam memutus perkara anak yangberkonflik dengan hukum, sebagian besarhakim pada Pengadilan

32 Elita Perwira Putri, "Analisis Dampak Pemenjaraan pada Anak Berkonflik dengan Hukum (ABH) di Lembaga Pemasyarakatan Anak”, Prosiding Seminar Nasional Psikologi 2016: Empowering Self, Fakultas Psikologi Universitas Islam Sultan Agung, Semarang, 2/ 4/2016, hlm. 84.

33 Putri, "Analisis Dampak Pemenjaraan pada Anak", hlm. 90-91. 
Tinggi Tanjung Karang cenderung menjatuhkan pidana penjara, sehingga asas kepentingan terbaik bagi anak belum sepenuhnya menjadi pertimbangan. Penerapan asas kepentingan terbaik bagi anak harus proporsional. Penerapan asas ini bak buah simalakama, di satu sisi bertujuan melindungi dan mengayomi anak yang berkonflik dengan hukum, namun di sisi lain ada kepentingan korban dan masyarakat yang harus dilindungi. Selain itu, tindak pidana yang dilakukan anak belum tentu bersumber dari hati nuraninya. Oleh karena itu, dalam hal tertentu penerapan asas kepentingan terbaik bagi anak dapat menjadi pilihan yang baik untuk melindungi hak dan masa depan anak. Namun di sisi lain penerapan asas kepentingan terbaik bagi anak dapat menjadi pilihan yang kurang baik, mengingat asas kepentingan terbaik menghendaki pemenjaraan sebagai pilihan terakhir, sehingga dikhawatirkan anak diperalat oleh orang dewasa untuk melakukan tindak pidana. Dalam penerapan asas kepentingan terbaik bagi anak, hakim harus berpedoman pada ketentuan normatif, keadilan yang hidup di masyarakat, keyakinan hakim itu sendiri dan kepentingan terbaik bagi anak. Oleh karenanya dalam penerapan asas ini hakim harus benar-benar cermat dan hati-hati agar tidak mengebiri hak salah satu pihak. Selain itu, aparat penegak hukum khususnya hakim harus berpedoman pada asas-asas dalam UU SPPA termasuk asas kepentingan terbaik bagi anak. ${ }^{34}$

\section{E. Kesimpulan}

Artikel ini menyimpulkan, pertama, fungsionalisasi asas kepentingan terbaik bagi anak yang berkonflik dengan hukum pada Pengadilan Tinggi Tanjung Karang belum optimal. Hal ini tampak dari sebagian besar putusan hakim yang masih berupa pidana penjara. Dari 22 perkara anak yang berkonflik dengan hukum sepanjang tahun 20112016, terdapat 16 perkara yang divonis pidana penjara. Selebihnya, enam perkara lagi, divonis dengan pidana bukan penjara. Dari 22 perkara anak yang diadili, terdapat tiga putusan yang dikategorikan

34 Supriyanta, "Kajian Normatif Penyelesaian Tindak Pidana Anak dalam Perspektif Due Process of Law”, Cakrawala Hukum, 14, 1 (2017), hlm. 57. 
telah mempertimbangkan asas kepentingan terbaik bagi anak. Dari ketiga putusan tersebut, dua di antaranya merupakan vonis pidana bukan penjara dan satu vonis penjara. Kedua, penerapan asas kepentingan terbaik bagi anak dapat berimplikasi positif maupun negatif. Ia berimplikasi positif, karena memberi perlindungan terhadap hak-hak anak dan masa depannya, serta meringankan beban pengadilan dan lembaga pemasyarakatan. Namun ia juga bisa berimplikasi negatif, karena dikhawatirkan tidak menimbulkan efek jera dan mengundang persepsi dan reaksi negatif masyarakat terhadap penegakan hukum di Indonesia. Oleh karenanya penerapan asas kepentingan terbaik baik bagi anak harus cermat dan proporsional agar tidak mengebiri hak anak.

\section{Daftar Pustaka}

\section{Artikel/Buku/laporan}

Atmasasmita, Romli. Problem Kenakalan Anak-Anak Remaja. Bandung: Amico, 1983.

Ekaputra, Mohammad. Dasar-Dasar Hukum Pidana. Medan: USU Press, 2010.

Farid, Zainal Abidin. Hukum Pidana I. Jakarta: Sinar Grafika, 2007. Fithri, Beby Suryani. "Asas Ultimum Remedium terhadap Anak yang Berkonflik dengan Hukum dalam Rangka Perlindungan Anak". Jurnal Mercatoria, 10, 1 (2017): 74-88. DOI: 10.31289/mercatoria. v10i1.733.g652

Gultom, Maidin. Perlindungan Hukum terhadap Anak dalam Sistem Peradilan Pidana Anak di Indonesia. Bandung: PT. Refika Aditama, 2008.

Hafiandy, Irzan, Madiasa Ablisar, Marlina, dan Mahmud Mulyadi.

"Penerapan Asas Kepentingan Terbaik Bagi Anak dalam Pelaksanaan Diversi”. USU Law Journal, 6, 5 (2018): 57-63.

Ibrahim, Rifki Septiawan dan Dientje Rumimpunu. "Hak-Hak Keperdataan Anak dalam Perspektif Undang-Undang Nomor 35 Tahun 2014 tentang Perlindungan Anak". Lex Privatum, 6, 2 (2018): 53-60. 
Irmayani, Nyi R. "Problematika Penanganan terhadap Anak Pelaku Tindak Kekerasan Seksual Selama Menjalankan Proses Hukum: Kasus di Provinsi Kalimantan Barat”. Sosio Konsepsia, 8, 3 (2019): 287-302. DOI: $10.33007 /$ ska.v8i3.1795.

Jafar, Kamaruddin. "Restorative Justice atas Diversi dalam Penanganan Juvenile Deliquency (Anak Berkonflik Hukum)”. Al-Adl, 8, 2 (2015): 81-101. DOI: 10.31332/aladl.v8i2.361.

Kartono, Kartini. Patologi Sosial 2 Kenakalan Remajai. Jakarta: Rajawali Press, 1992.

Mamentu, Olvina Kartika. "Peran Pasal 2 Undang-Undang Nomor 11 Tahun 2012 tentang Sistem Peradilan Pidana Anak terhadap Anak yang Berkonflik dengan Hukum”. Lex Crimen, 4, 2 (2015): 140-150.

Marlina. Pengantar Konsep Diversi dan Restoratif justice dalam Hukum Pidana. Medan: USU Press, 2010.

Mas, Marwan. Pengantar Ilmu Hukum. Jakarta: Ghalia, 2004.

Mertokusumo, Sudikno. Penemuan Hukum Sebuah Pengantar. Jakarta: Liberty, 2009.

Ohoiwutun, Y.A.T. "Urgensi Bedah Mayat Forensik dalam Pembuktian Tindak Pidana Pembunuhan Berencana: Kajian Putusan Nomor 79/Pid.B/2012/PN.BGR”. Jurnal Yudisial, 9, 1 (2016): 73-92. DOI: $10.29123 /$ jy.v9i1.32.

Ohoiwutun, Y. A Triana dan Samsudi. "Penerapan Prinsip Kepentingan Terbaik Bagi Anak dalam Kasus Tindak Pidana Narkotika Kajian Putusan Nomor 229/Pid.B/2012/PN.Jpr”. Jurnal Yudisial, 10, 1 (2017): 39-57. DOI: 10.29123/jy.v10i1.41.

Prasetyo, Teguh. "Penerapan Diversi terhadap Tindak Pidana Anak dalam Sistem Peradilan Pidana Anak". Refleksi Hukum: Jurnal Ilmu Hukum, 9, 1 (2015): 1-14. DOI: 10.24246/jrh.2015.v9.11.p114.

Putri, Elita Perwira. "Analisis Dampak Pemenjaraan pada Anak Berkonflik dengan Hukum (ABH) di Lembaga Pemasyarakatan Anak”. Prosiding Seminar Nasional Psikologi 2016: Empowering Self, Fakultas Psikologi Universitas Islam Sultan Agung, Semarang, 2/4/2016, 82-94. 
Sari, Novita. "Penerapan Asas Ultimum Remedium dalam Penegakan Hukum Tindak Pidana Penyalahgunaan Narkotika”. Jurnal Penelitian Hukum De Jure, 17, 3 (2017): 351-363. DOI: 10.30641/ dejure.2017.V17.351-363.

Sudarto. Hukum Pidana I. Semarang: Yayasan Sudarto, 1990.

Sukoco, Bambang. "Prospek dan Dilema Penerapan Restoratif Justice Sistem dalam Kasus Pidana Anak". Jurnal Ilmu Hukum, 14, 2 (2011): 335-346.

Suparmin. "Kebijakan Hukum Pidana dalam Tindak Pidana yang Dilakukan Anak”. Qistie: Jurnal Ilmu Hukum, 1, 1 (2008). DOI: 10.31942/jqi.v1i1.877.

Supriyanta. "Kajian Normatif Penyelesaian Tindak Pidana Anak dalam Perspektif Due Process of Law”. Cakrawala Hukum, 14, 1 (2017): 47-58.

Syachdin. "Application of the Ultimum Remedium Principle to the Children Involved in Narcotic". Tadulako Law Review, 1, 2 (2016): 197-213. DOI: 10.22487/j25272985.2016.v1.i2.7131.

Syakirin, Ahmad. "Formulasi/Model Sistem Pemidanaan Anak di Indonesia”. Mimbar Yustitia, 2, 2 (2018): 121-141.

Tongat. Dasar-Dasar Hukum Pidana di Indonesia dalam Perspektif Pembaharuan. Malang: UMM Press, 2009.

Wahyudi, Dheny. "Perlindungan terhadap Anak yang Berhadapan dengan Hukum Melalui Pendekatan Restorative Justice”. Jurnal Ilmu Hukum, 6, 1 (2015): 143-163.

Zahra, Afni dan RB. Sularto. "Penerapan Asas Ultimum Remedium dalam Rangka Perlindungan Anak Pecandu Narkotika”. Law Reform, 13, 1 (2017): 18-27. DOI: 10.14710/lr.v13i1.15948.

\section{Peraturan Hukum}

Republik Indonesia. Undang-Undang Nomor 39 Tahun 1999 tentang

Hak Asasi Manusia. Lembaran Negara Tahun 1999 Nomor 165, Tambahan Lembaran Negara Nomor 3886.

Republik Indonesia. Undang-Undang Nomor 23 Tahun 2002 tentang

Perlindungan Anak. Lembaran Negara Tahun 2002 Nomor 109, Tambahan Lembaran Negara Nomor 4235. 
Mashuril Anwar \& M. Ridho Wijaya

Republik Indonesia. Undang-Undang Nomor 11 Tahun 2012 tentang Sistem Peradilan Pidana. Lembaran Negara Tahun 2012 Nomor 153, Tambahan Lembaran Negara Nomor 5332. 